\title{
Two New Flavonol Glycosides from Sarcopyramis bodinieri var. delicate
}

\section{Xiu Min Wang ${ }^{1}$, Chun Peng Wan ${ }^{1,2}$, Shou Ran Zhou ${ }^{2}$ and Yan Qiu ${ }^{1, *}$}

${ }^{1}$ Department of Pharmacy, School of Medical, Xiamen University, Xiamen 361005, People's Republic of China; E-mail: wangxm@xmu.edu.cn.

2 Jiangxi University of Traditional Chinese Medicine, Nanchang 330006, People's Republic of China; E-mail: lemonwan@126.com (Wan).E-mail: 9x8f@163.com (Zhou).

* Author to whom correspondence should be addressed. E-mail: yanqiu@xmu.edu.cn; Tel: (+86) 5922188681; Fax: (+86) 592-2188676

Received: 4 June 2008; in revised form:17 June 2008 / Accepted: 17 June 2008 / Published: 19 June 2008

\begin{abstract}
Detailed chemical investigation of the herb Sarcopyramis bodinieri var. delicate resulted in the isolation of two new flavonol glycosides, namely, isorhamnetin-3-O-(6"-O$E$-feruloyl)- $\beta$-D-glucopyranoside (1) and isorhamnetin-3- $O$-(6"- $O$ - $E$-feruloyl)- $\beta$-Dgalactopyranoside (2). In addition, four known compounds, quercetin-3- $O$-(6"-acetyl)- $\beta$-Dglucopyranoside (3), isorhamnetin-3- $O$-(6"-acetyl)- $\beta$-D-glucopyranoside (4), quercetin-3$O$-(6"-O-E-p-coumaroyl)- $\beta$-D-glucopyranoside (5), and isorhamnetin-3-O-(6"'-O-E- $p$ coumaroyl)- $\beta$-D-glucopyranoside (6) were obtained. The structures of the new isolates were determined by extensive spectroscopic analysis.
\end{abstract}

Keywords: Sarcopyramis bodinieri var. delicate, flavonol glycoside.

\section{Introduction}

Members of the Melastomataceae family are widespread in many regions of the world and particularly in tropical and subtropical regions, mainly in South America and South China. Many species of this family are known by their different use in folk medicine as antioxidant [1], 
antihypertensive [2], antihyperglycemic [3], hemostatic [4] and antihepatitis drugs [5]. Antiinflammatory [4], antimicrobial [6] and cytotoxic effects [1] have also been investigated. Cumulative phytochemical studies of Melastomataceous plants have indicated an abundance of tannins [7], polyphenols [7], flavonoids [8], fatty acids, steroids, and free triterpenoids [9]. The great variety of natural compounds found in this family, as well as their pharmacological properties prompted us to study the chemical constituents and bioactivities of Sarcopyramis bodinieri var. delicate, an endemic and chemically uninvestigated plant distributed widely in South China.

As a rare species, Sarcopyramis bodinieri var. delicate was widely used as hepatoprotective drug in Fujian province, China. The water extract of this dried herb could reduce aminotransferase and cure choloplania and hepatoma. Detailed fractionation led to the isolation of two new flavonol glycosides, namely, isorhamnetin-3-O-(6"-O-E-feruloyl)- $\beta$-D-glucopyranoside (1) and isorhamnetin-3-O-(6"-O-Eferuloyl)- $\beta$-D-galactopyranoside (2), along with four known compounds. The structures of the new isolates were determined by extensive spectroscopic analysis.

Figure 1. The structures of new compounds 1 and 2.

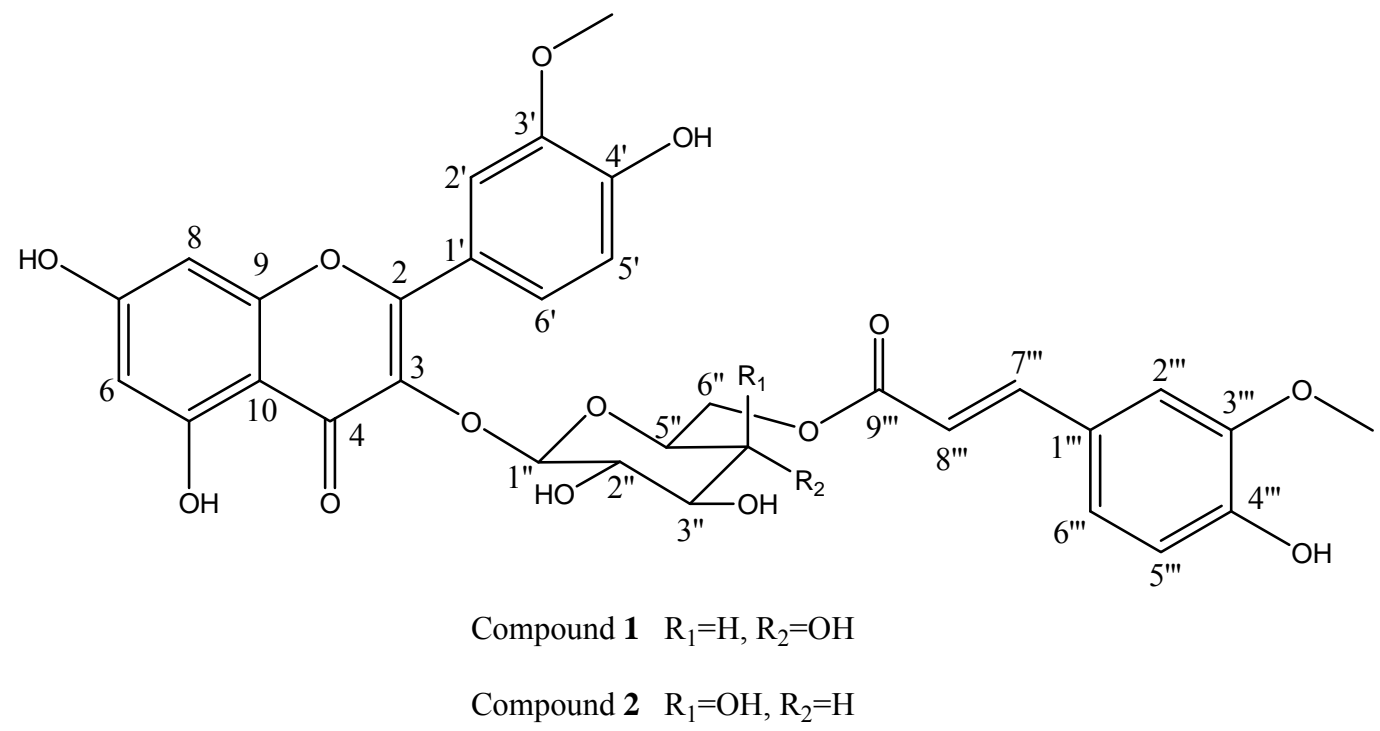

\section{Results and Discussion}

The known compounds 3-6 corresponded to quercetin-3-O-(6"-acetyl)- $\beta$-D-glucopyranoside (3) $[10]$, isorhamnetin-3- $O$-(6"-acetyl)- $\beta$-D-glucopyranoside (4) $[11]$, quercetin-3-O-(6" $-O-E-p$ coumaroyl)- $\beta$-D-glucopyranoside (5) $\quad[12]$, and isorhamnetin-3- $O$-(6"- $O-E$ - $p$-coumaroyl)- $\beta$-Dglucopyranoside (6) $[13,14]$. The structures of these known flavonol glycosides were identified on the basis of extensive spectroscopic data analysis and by comparison of their spectral data with those reported in the literature. 
Figure 2. The structures of compounds 3-6.
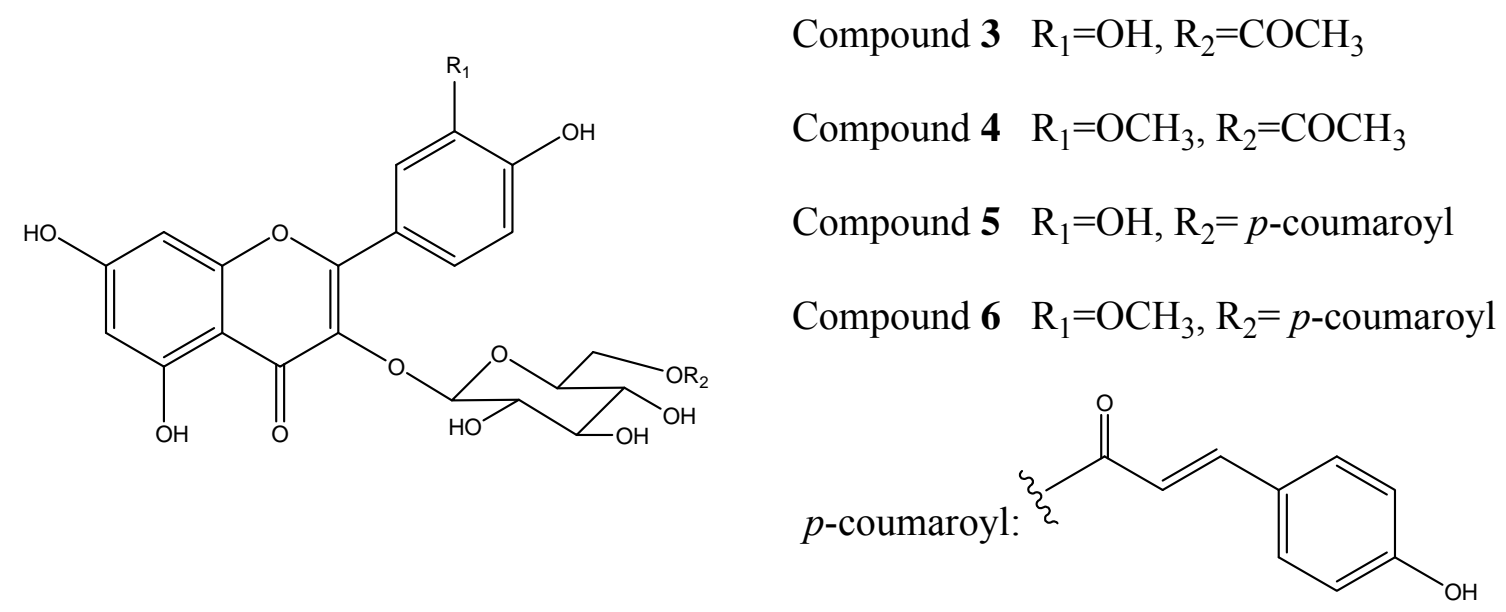

Compound 1 was isolated as a yellow powder. The molecular formula $\mathrm{C}_{32} \mathrm{H}_{30} \mathrm{O}_{15}$ was suggested by a mass spectrum with a $[\mathrm{M}+\mathrm{Na}]^{+}$peak at $\mathrm{m} / z$ 677, further confirmed by the adduct ions: $693[\mathrm{M}+\mathrm{K}]^{+}$, and $1331[2 \mathrm{M}+\mathrm{Na}]^{+}$, combined with the ${ }^{13} \mathrm{C}-\mathrm{NMR}$ and DEPT spectra. The IR spectrum of compound $\mathbf{1}$ revealed the aliphatic and aromatic hydroxyl signals at $3200-3550 \mathrm{~cm}^{-1}$. A conjugated carbonyl group $\left(1656 \mathrm{~cm}^{-1}\right)$ and an additional $\alpha, \beta$-unsaturated carbonyl ester group $\left(1724 \mathrm{~cm}^{-1}\right)$ were observed in the same region. The absorptions at 3310 and $1057 \mathrm{~cm}^{-1}$ indicated the presence of a glycosidic moiety [15].

The ${ }^{1} \mathrm{H}-\mathrm{NMR}$ spectrum confirmed many of the above features and revealed a set of isorhamnetin signals, a feruloyl group and a glucopyranose moiety. The presence of isorhamnetin was suggested by the following signals: two doublets at $\delta_{\mathrm{H}} 6.14(\mathrm{~d}, J=1.8 \mathrm{~Hz}, \mathrm{H}-6)$ and $6.37(\mathrm{~d}, J=1.8 \mathrm{~Hz}, \mathrm{H}-8)$; an $\mathrm{ABX}$ spin system due to the aromatic ring at $\delta_{\mathrm{H}} 6.90\left(\mathrm{~d}, J=8.6 \mathrm{~Hz}, \mathrm{H}-5^{\prime}\right), 7.52(\mathrm{dd}, J=8.6,1.9 \mathrm{~Hz}, \mathrm{H}-$ $\left.6^{\prime}\right)$ and $7.87\left(\mathrm{~d}, J=1.9 \mathrm{~Hz}, \mathrm{H}-2^{\prime}\right)$; a methoxyl group singlet at $\delta_{\mathrm{H}} 3.86\left(\mathrm{~s}, 3^{\prime}-\mathrm{OMe}\right)$ with a HMBC correlation with $\delta_{\mathrm{C}} 147.1\left(\mathrm{C}-3^{\prime}\right)$ [16]. In the ${ }^{1} \mathrm{H}-\mathrm{NMR}$ spectrum another set of ABX-type aromatic proton signals at $\delta_{\mathrm{H}} 6.75\left(\mathrm{~d}, J=8.1 \mathrm{~Hz}, \mathrm{H}-5^{\prime \prime \prime}\right), 6.88\left(\mathrm{dd}, J=8.1,1.2 \mathrm{~Hz}, \mathrm{H}-6^{\prime \prime \prime}\right)$ and $7.20(\mathrm{~d}, J=1.2$ $\left.\mathrm{Hz}, \mathrm{H}-2^{\prime \prime \prime}\right)$ were observed, together with an additional HMBC crosspeak between $\delta_{\mathrm{H}} 3.82\left(\mathrm{~s}, 3^{\prime \prime \prime}-\mathrm{OMe}\right)$ and $\delta_{\mathrm{C}} 147.9\left(\mathrm{C}-3^{\prime \prime \prime}\right)$. Two olefinic protons with a trans coupling constant $(J=15.8 \mathrm{~Hz})$ at $\delta_{\mathrm{H}} 6.22(\mathrm{~d}$, $\left.\mathrm{H}-8^{\prime \prime \prime}\right), 7.34$ (d, H-7'"'), which confirmed the presence of an $\alpha, \beta$-unsaturated carbonyl ester group. The feruloyl structure was then deduced from the HMBC correlation from $\delta_{\mathrm{H}} 6.22\left(\mathrm{H}-8^{\prime \prime \prime}\right)$ to $\delta_{\mathrm{C}} 126.4(\mathrm{C}$ $\left.1^{\prime \prime \prime}\right)$ and the crosspeaks between $\mathrm{H}-2^{\prime \prime \prime} / \mathrm{C}-7^{\prime \prime \prime}$ and H-6"'/C-7"'. Detailed analyses of the ${ }^{1} \mathrm{H}-(\delta 5.53, \mathrm{~d}, J$ $\left.=7.8 \mathrm{~Hz}, \mathrm{H}-1^{\prime \prime}\right)$ and ${ }^{13} \mathrm{C}-\mathrm{NMR}(\delta 102.8,77.8,76.1,76.0,71.8,64.2)$ suggested glucopyranose as the sugar moiety. A downfield shift of C-6" was from $\delta_{\mathrm{C}} 61.8$ to 64.2 , and an upfield shift of C-5" was from $\delta_{\mathrm{C}} 76.8$ to 76.0 , which were in accordance with the acylation of C- $6^{\prime \prime}$ of the glucose moiety [17]. Moreover, the downfield shift of $\mathrm{H}_{2}-6^{\prime \prime}$ to 4.11 (dd, $\left.J=6.8,11.5 \mathrm{~Hz}\right)$ and 4.19 (dd, $J=2.1,11.5 \mathrm{~Hz}$ ) further confirmed the presence of a C- 6 " feruloyl in compound 1 [18]. Consequently, the structure of compound 1 was established as isorhamnetin-3-O-(6"-O-E-feruloyl)- $\beta$-D-glucopyranoside.

Compound 2, a yellow powder, shared the same molecular formula $\mathrm{C}_{32} \mathrm{H}_{30} \mathrm{O}_{15}$ with $\mathbf{1}$, according to the $[\mathrm{M}+\mathrm{Na}]^{+}$peak at $m / z 677$ and $[\mathrm{M}+\mathrm{K}]^{+}$peak at $m / z$ 693. Moreover, its NMR data is very similar to those of 1. Detailed comparison of the ${ }^{13} \mathrm{C}-\mathrm{NMR}$ and HMQC spectra between the two compounds indicated that the major difference was in the glycoside moiety. The carbon signals at $\delta_{\mathrm{C}} 103.4\left(\mathrm{C}-1^{\prime \prime}\right)$, $71.2\left(\mathrm{C}-2^{\prime \prime}\right), 74.6\left(\mathrm{C}-3^{\prime \prime}\right), 69.5\left(\mathrm{C}-4^{\prime \prime}\right), 74.3\left(\mathrm{C}-5^{\prime \prime}\right)$, and $62.9\left(\mathrm{C}-6^{\prime \prime}\right)$ revealed a galactopyranoside 
moiety [16]. The structure of compound 2 was therefore assigned as isorhamnetin-3-O-(6"-O-Eferuloyl)- $\beta$-D-galactopyranoside.

Table 1. The ${ }^{1} \mathrm{H}$ and ${ }^{13} \mathrm{C}-\mathrm{NMR}$ data of compounds 1 and 2 (DMSO- $d_{6}$ ).

\begin{tabular}{|c|c|c|c|c|}
\hline \multirow[t]{2}{*}{ No. } & \multicolumn{2}{|c|}{ Compound 1} & \multicolumn{2}{|c|}{ Compound 2} \\
\hline & $\mathrm{H}\left(J_{\mathrm{Hz}}\right)$ & $\mathrm{C}$ & $\mathrm{H}\left(J_{\mathrm{Hz}}\right)$ & $\mathrm{C}$ \\
\hline 2 & & 157.6 & & 157.5 \\
\hline 3 & & 134.3 & & 134.3 \\
\hline 4 & & 178.6 & & 178.5 \\
\hline 5 & & 162.3 & & 162.2 \\
\hline 6 & $6.14 \mathrm{~d}(1.8)$ & 99.6 & $6.15 \mathrm{~d}(1.8)$ & 99.5 \\
\hline 7 & & 165.1 & & 165.1 \\
\hline 8 & $6.37 \mathrm{~d}(1.8)$ & 94.9 & $6.37 \mathrm{~d}(1.8)$ & 94.7 \\
\hline 9 & & 157.6 & & 157.5 \\
\hline 10 & & 104.9 & & 104.9 \\
\hline $1^{\prime}$ & & 122.3 & & 122.2 \\
\hline $2^{\prime}$ & $7.87 \mathrm{~d}(1.9)$ & 114.2 & $7.99 \mathrm{~d}(1.9)$ & 114.5 \\
\hline $3^{\prime}$ & & 147.1 & & 147.1 \\
\hline $4^{\prime}$ & & 150.7 & & 150.6 \\
\hline $5^{\prime}$ & $6.90 \mathrm{~d}(8.6)$ & 116.1 & $6.89 \mathrm{~d}(8.6)$ & 116.2 \\
\hline $6^{\prime}$ & $7.52 \mathrm{dd}(8.6,1.9)$ & 122.9 & $7.50 \mathrm{dd}(8.6,1.9)$ & 122.9 \\
\hline $1^{\prime \prime}$ & $5.53 \mathrm{~d}(7.8)$ & 102.8 & $5.52 \mathrm{~d}(7.8)$ & 103.4 \\
\hline $2^{\prime \prime}$ & $3.26 \mathrm{~m}$ & 76.1 & $3.20 \mathrm{~m}$ & 71.2 \\
\hline $3^{\prime \prime}$ & $3.28 \mathrm{~m}$ & 77.8 & $3.48 \mathrm{~m}$ & 74.6 \\
\hline $4^{\prime \prime}$ & $3.62 \mathrm{~m}$ & 71.8 & $3.70 \mathrm{~m}$ & 69.5 \\
\hline $5^{\prime \prime}$ & $3.43 \mathrm{~m}$ & 76.0 & $3.74 \mathrm{~m}$ & 74.3 \\
\hline \multirow[t]{2}{*}{$6^{\prime \prime}$} & $4.11 \mathrm{dd}(6.8,11.5)$ & 64.2 & $4.12 \mathrm{dd}(7.0,11.8)$ & 62.9 \\
\hline & $4.19 \mathrm{dd}(2.1,11.5)$ & & $4.24 \mathrm{dd}(2.1,11.8)$ & \\
\hline $1^{\prime \prime \prime}$ & & 126.4 & & 126.4 \\
\hline $2^{\prime \prime \prime}$ & $7.20 \mathrm{~d}(1.2)$ & 112.1 & $7.19 \mathrm{~d}(1.2)$ & 111.7 \\
\hline $3^{\prime \prime \prime}$ & & 147.9 & & 147.8 \\
\hline $4^{\prime \prime \prime}$ & & 150.3 & & 150.4 \\
\hline $5^{\prime \prime \prime}$ & $6.75 \mathrm{~d}(8.1)$ & 116.4 & $6.78 \mathrm{~d}(8.0)$ & 116.4 \\
\hline $6^{\prime \prime \prime}$ & $6.88 \mathrm{dd}(8.1,1.2)$ & 123.8 & $6.88 \mathrm{dd}(8.0,1.2)$ & 124.0 \\
\hline $7^{\prime \prime \prime}$ & $7.34 \mathrm{~d}(15.8)$ & 145.9 & $7.34 \mathrm{~d}(15.8)$ & 146.0 \\
\hline $8^{\prime \prime \prime}$ & $6.22 \mathrm{~d}(15.8)$ & 115.1 & $6.26 \mathrm{~d}(15.8)$ & 113.8 \\
\hline $9^{\prime \prime \prime}$ & & 167.5 & & 167.2 \\
\hline 3'-OMe & 3.86 & 56.9 & 3.87 & 56.8 \\
\hline $3^{\prime \prime \prime}-\mathrm{OMe}$ & 3.82 & 56.6 & 3.78 & 56.2 \\
\hline
\end{tabular}


The UV spectra of the different flavonol glycosides showed an interesting phenomenon (see Table 2) according to our experiments. The substituted fraction on the glycosidic moiety could be characterized by the absorption over $300 \mathrm{~nm}$. For example, the absorption maxima at $315 \mathrm{~nm}$ means a $p$-substituted aromatic ring in $\mathrm{R}_{2}$, while the absorption at 330-336 nm indicates a tri-substituted aromatic ring in the same position.

Table 2. The UV data for different flavonol glycosides.<smiles>O=c1c(OC(O)C(O)CO)c(-c2ccc(O)c(Br)c2)oc2cc(O)cc(O)c12</smiles>

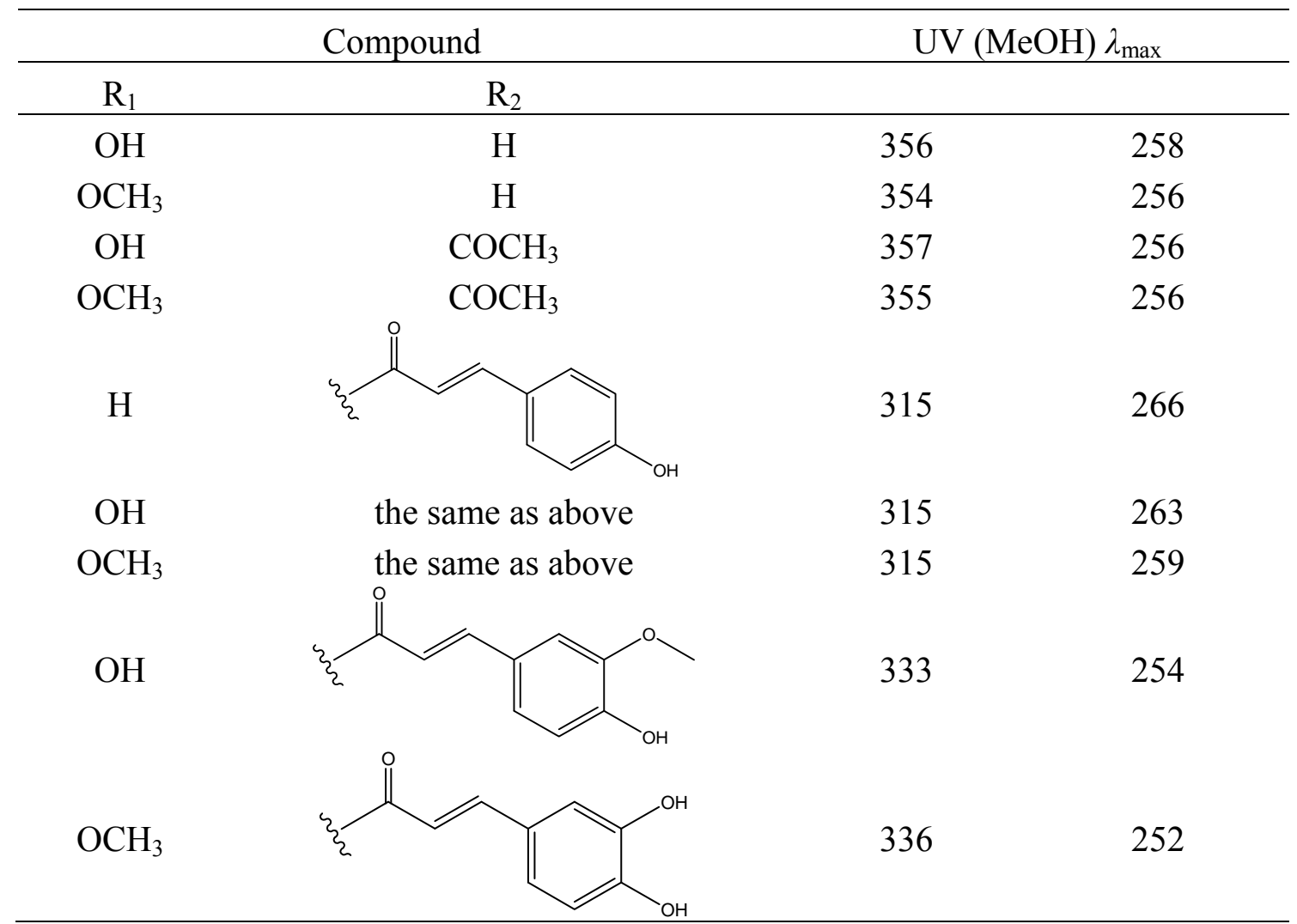

\section{Experimental}

\section{General}

The IR spectra were determined on a Thermo Nicolet Nexus 470 FT-IR spectrometer. Optical rotations were measured with a Perkin-Elmer 243 B polarimeter using a $1 \mathrm{dm}$ microcell. The ${ }^{1} \mathrm{H}-\mathrm{NMR}$ and ${ }^{13} \mathrm{C}$-NMR spectra were recorded on a Bruker Avance-600 FT NMR spectrometer. ESI-MS were recorded on a PE Q-STAR ESI-TOF-MS/MS spectrometer. Column chromatography was carried with silica gel (200-300 mesh), and $\mathrm{HF}_{254}$ silica gel for TLC was obtained from Qingdao Marine Chemistry 
Co. Ltd., Qingdao, People's Republic of China. ODS and Sephadex LH-20 (18-110 $\mu \mathrm{m})$ were obtained from Pharmacia Co.

\section{Extraction and Isolation}

The specimen of Sarcopyramis bodinieri var. delicate was collected from Fujian Province, P.R. China, in April 2007. A voucher specimen (RSC07) is deposited at the Department of Pharmacy, School of Medical, Xiamen University. The air-dried plant material $(5 \mathrm{~kg})$ was ground and extracted exhaustively by maceration at room temperature with $\mathrm{EtOH}-\mathrm{H}_{2} \mathrm{O}(70: 30,20 \mathrm{~L} \times 3)$. The concentrated total extract $(1.8 \mathrm{~kg})$ was extracted with petroleum ether, $\mathrm{CHCl}_{3}$, EtOAc and $n-\mathrm{BuOH}$, respectively. Part of the EtOAc portion (SBC, $45 \mathrm{~g}$ ) was suspended in $\mathrm{H}_{2} \mathrm{O}(2 \mathrm{~L})$, and the filter layer was then subjected to D101 macroporous adsorption resin column, eluted with an equivalent $\mathrm{H}_{2} \mathrm{O}-\mathrm{EtOH}$ stepwise gradient to obtain 5 fractions. Fraction 3 (SBC-C, 13.76 g) was subjected to a Sephadex LH20 eluted with $\mathrm{MeOH}-\mathrm{H}_{2} \mathrm{O}$ (3:1) to give 6 fractions. Fr. SBC-C3 was subjected to Sephadex LH-20 column and then the repeated silica gel column to give compounds 3 (16.7 mg), 4 (33.4 mg), 5 (18.2 $\mathrm{mg}), 6$ (7.5 mg). Compounds 1 and 2 were repurified from SBC-C3C by semi-preparative reversedphased HPLC $\left(45 \% \mathrm{MeOH}-\mathrm{H}_{2} \mathrm{O}\right.$, YMC-Pack Pro C-18, 20×150 mm) to give $4.6 \mathrm{mg}$ and $5.8 \mathrm{mg}$, respectively.

Compound 1: $[\alpha]_{D}^{25}=-48.6\left(c\right.$ 0.67, MeOH); UV (MeOH) $\lambda_{\max }(\log \varepsilon) 251$ (4.53), 333 (3.21) nm; IR (neat) $v_{\max } 3550,1724,1656,1057 \mathrm{~cm}^{-1}$; for ${ }^{1} \mathrm{H}$ and ${ }^{13} \mathrm{C}-\mathrm{NMR}$ see Table 1; ESI-TOF MS $(\mathrm{m} / z): 677$ $[\mathrm{M}+\mathrm{Na}]^{+}, 693[\mathrm{M}+\mathrm{K}]^{+}, 1331[2 \mathrm{M}+\mathrm{Na}]^{+}$.

Compound 2: $[\alpha]_{D}^{25}=-64.2$ (c 0.24, MeOH); UV (MeOH) $\lambda_{\max }(\log \varepsilon) 249$ (4.47), 334 (3.20) nm; for ${ }^{1} \mathrm{H}$ and ${ }^{13} \mathrm{C}-\mathrm{NMR}$ see Table 1; ESI-TOF MS $(\mathrm{m} / \mathrm{z}): 677[\mathrm{M}+\mathrm{Na}]^{+}, 693[\mathrm{M}+\mathrm{K}]^{+}$.

\section{Acknowledgements}

This project was supported by the National Natural Sciences Foundation of China (No. 30600053) and Fujian Key Foundation of Science and Technology (No. 2005YZ1025).

\section{References}

1. Susanti, D.; Sirat, H. M.; Ahmad, F.; Ali, R. M.; Aimi, N.; Kitajima, M. Antioxidant and cytotoxic flavonoids from the flowers of Melastoma malabathricum L. Food Chem. 2007, 103, 710-716.

2. Cheng, J. T.; Hsu, F. L.; Chen, H. F. Antihypertensive priciples from the leaves of Melastoma candidium. Planta Med. 1993, 59, 405-407.

3. Amalraj, T.; Ignacimuthu, S. Evaluation of the hypoglycaemic effect of Memecylon umbellatum in normal and alloxan diabetic mice. J. Ethnopharmacol. 1998, 62, 247-250.

4. Ishiii, R.; Saito, K.; Horie, M.; Shibano, T.; Kitanaka, S.; Amano, F. Inhibitory effects of hydrolyzable tannins form melastoma dodecandrum lOUR on nitric oxide production by a murine 
macrophage-like cell line, RAW264.7, activated with lipopolysaccharide and interferon- $\gamma$. Biol. Pharm. Bull. 1999, 22, 647-653.

5. Nicholl, D. S.; Daniels, H. M.; Thabrew, M. I.; Grayer, R. J.; Simmonds, M. S. J.; Hughes, R. D. In vitro studies on the immunomodulatory effect extracts of Osbeckia aspera. J. Ethnopharmacol. 2001, 78, 39-44.

6. Ventura, C. P.; Braga de Oliveira, A.; Braga, F. C. Antimicrobial activity of Trembleya laniflora, Xyris platystachia and Xyris pterygoblephara. Rev. Bras. Farma. 2007, 17, 17-22.

7. Yoshida,T.; Arioka, H.; Fujita, T.; Chen, X. M.; Okuda, T. Monomeric and dimeric hydrolysable tannins from two melastomataceous species. Phytochemistry 1994, 37, 863-866

8. Isaza, J. H.; Ito, H.; Yoshida, T. A flavonol glycoside-lignan ester and accompanying acylated glucosides from Monochaetum muliflorum. Phytochemistry 2001, 58, 321-327.

9. Calderón, A. I.; Terreaux, C.; Schenk, K.; Pattison, P.; Burdette, J. E.; Pezzuto, J. M.; Gupta, M. P.; Hostettmann K. Isolation and structure elucidation of an isoflavone and a sesterterpec acid from Henriettella fascicularis. J. Nat. Prod. 2002, 65, 1749-1753.

10. Xiong, Q. B.; Fan, W. Z.; Tezuka, Y.; Adnyana, I. K.; Stampoulis, P.; Hattori, M.; Namba, T.; Kadota, S. Hepatoprotective effect of Apocynum venntum and its active constituents1 Planta Med. 2000, 66, 127-133.

11. Pan, H.; Lundgren, L. N. Phenolic extractives from root bark of Picea abies. Phytochemistry 1995, 39, 1423-1428.

12. Wagner, H.; Iyengar, M. A.; Michahelles, E.; Herz, W. Quercetin-3-( $O$-acetyl)- $\beta$-Dglucopyranosid in Plummera floribunda und Helenium hoopesii. Phytochemistry 1971, 10, 25472548.

13. Zadororhny, A. M.; Zapesochnaya, G. G.; Pervykh, L. N; Shehavlinsky, A. N.; Kovtum, L. S.; Svanidze, N. V. Investigation of the herb Aerva lanata. I. O-acylglycosides of flavonoids. Khim. Farm. Zhur. 1986, 20, 855-858.

14. Karioti, A.; Skaltsa, H.; Heilmann, J.; Sticher, O. Acylated flavonoid and phenylethanoid glycosides from Marrubium velutinum. Phytochemistry 2003, 64, 655-660.

15. Catalono, S.; Bilia, A. R.; Martinozzi, M.; Morelli, I. Kaempferol 3-O- $\beta$-D-(6"-feruloylglucoside) from Polylepis incana. Phytochemistry 1994, 37, 1777-1778.

16. Calzada, F.; Cedillo-Rivera, R.; Mata, R. Antiprotozoal activity of the constituents of Conyza filaginoides. J. Nat. Prod. 2001, 64, 671-673.

17. Itokawa, H.; Suto, K.; Takeya, K. Structures of isoagastachoside and agastachin, new glucosylflavones isolated from Agastache rugosa. Chem. Pharm. Bull. 1981, 29, 1777-1779.

18. Bahuguna, R. P.; Jangwan, J. S.; Kaiya, T.; Sakakibara. J. Puddumin-A, a New Flavanone Glucoside from Prunus cerasoides. J. Nat. Prod. 1987, 50, 232-234.

Sample Availability: Samples of the compounds are available from the authors.

(C) 2008 by the authors; licensee Molecular Diversity Preservation International, Basel, Switzerland. This article is an open-access article distributed under the terms and conditions of the Creative Commons Attribution license (http://creativecommons.org/licenses/by/3.0/). 